\title{
Preparation and medical follow-up for a single-handed transatlantic rowing race
}

\author{
Mathieu Carron ${ }^{1}$, Mathieu Coulange ${ }^{2,3}$, Christophe Dupuy $^{2}$, Pierre Mastalski $^{2}$, Bruno Barberon ${ }^{2,3}$, \\ Alexis Roullaud ${ }^{2,3}$, Agnalys Desplantes ${ }^{2,3}$, Jean-Pierre Auffray, 3 \\ ${ }^{1}$ Emergency Department, Pasteur 2 University Hospital, Nice, France \\ ${ }^{2}$ Mediterranean Medical Society for Maritime Emergency (SMMUM), Marseilles, France \\ ${ }^{3}$ Department of Emergency Medicine, Critical Care and Hyperbaric Medicine, University Hospital, Marseilles, France
}

\begin{abstract}
Background: A single-handed transatlantic rowing race was organised between Senegal and French Guyana (2600 nautical miles). During the race, rowers adjust their lifestyle to maintain an optimal level of performance. Nutrition, circadian rhythm disturbance, psychological state, pain and other medical problems impact on physical abilities and increase the occurrence of accidents. We surveyed the prevalence of medical complications during this race and the preparation that we could suggest for this kind of activity. Materials and methods: This is a descriptive, retrospective case series study. Follow-up consisted of sending out a questionnaire and performing individual interviews.

Results: A total of 23 participants including 1 woman and 22 men; mean age of 46.5 years (range: 35-59) entered the race. The race lasted for 39 to 52 days with participants rowing between 10 and $12 \mathrm{~h} /$ day. Nine participants dropped out. Energy intake was 4500 to $6000 \mathrm{kcal} /$ day and fluid intake was 4 to $5.5 \mathrm{~L} /$ /day. Mean weight loss was $13.3 \mathrm{~kg}$. The resting period was $6 \pm 1 \mathrm{~h} / 24 \mathrm{~h}$ divided into 1.5 to $2 \mathrm{~h}$ periods essentially during darkness. A total of $92 \%$ of the racers required medical care for dermatological problems; other conditions requiring medical care were: tendinitis in 10 cases, diarrhoea in 4, moderate to severe seasickness in 4, hallucinations in 3, panic attacks in 2, burns in 2, and disembarkation syndrome ("land sickness") lasting from $45 \mathrm{~min}$ to $6 \mathrm{~h}$ in 13.

Conclusions: Physiological and psychological impact of this type of event is still unclear. The most common medical problems are dermatological, rheumatological complications and minor trauma. Medical and psychological preparation should be offered to candidates for these competitions.
\end{abstract}

(Int Marit Health 2017; 68, 1: 7-11)

Key words: maritime injuries, transatlantic, rowing race, sport medicine

\section{INTRODUCTION}

The "Bouvet-Guyane" is a single-handed transatlantic rowing race, from Dakar in Senegal to Cayenne in French Guyana. This type of event helps to better understand the physiology and pathology associated with prolonged exposure to the elements, over 4 to 7 weeks at sea, in order to race 2600 nautical miles (approximately $4700 \mathrm{~km}$ ). Boats are the oceanic type, 26 feet $(8 \mathrm{~m}$ ) long by 5.2 feet $(1.6 \mathrm{~m}$ ) wide. The intensive nature of rowing sports leads to injuries in athletes. The main musculoskeletal injuries observed are knee pain, lower back pain and costal stress fractures [1, 2]. During the race, rowers fine-tune their lifestyle to maintain an optimal level of performance. Food, circadian rhythm, psychological state, pain and other medical problems impact on this fragile equilibrium. A disciplined preparation is achieved on land beforehand thanks to contestants' self-knowledge and previous experience. In order to improve these training programmes and maximise participants' safety, it is necessary to improve our knowledge of physiological conditions at sea by collecting objective medical data. Studies of Oceanic rowers have looked into diet [3] or musculoskeletal strength in an anthropological study [4]. The aims of our study are to assess lifestyle disturbance and medical problems encountered by contestants during the single-handed transatlantic rowing race. 
Table 1. Rowing time and time at sea per rower

\begin{tabular}{lllll}
\hline Rower/Sex & Time at sea* & Rowing time** & Notal/24 h \\
\cline { 3 - 5 } & & Day & 8 & 10 \\
\hline A/Male & 41 & 8 & 3 & 12 \\
B/Male & 38 & 9.5 & 1 & 8.5 \\
C/Male & 24 & 9 & 3 & 12 \\
D/Male & 39 & 8 & 2 & 10 \\
E/Female & 8 & 10 & 0 & 10 \\
F/Male & 40 & 9 & 2 & 11 \\
G/Male & 38 & 9 & 0 & 9 \\
H/Male & 48 & 10 & 0 & 10 \\
I/Male & 42 & 8 & 2 & 10 \\
J/Male & 46 & 9 & 1 & 10 \\
K/Male & 52 & 11 & 0 & 11 \\
L/Male & 39 & 15.7 & 1.3 & 10.3 \\
Average & 37.9 & 9 & 2 & 10
\end{tabular}

*Time at sea is displayed in days; ${ }^{*}$ Rowing time is displayed in hours

\section{MATERIALS AND METHODS}

This is a descriptive, retrospective case series study. Data were collected through a questionnaire organised into 8 sections (General Information, Food and diet, Hydration, Sleep, Medicines, Environment, Mental well-being and Boat) and 62 items. It was sent to each contestant at the end of the race and filled in anonymously. The race's website [5] was used to extract demographics and race duration. All Bouvet-Guyane contestants, including people who dropped out for any reason, were included in this study. Missing quantitative results were excluded from the study. When no answer was given regarding seasickness and land sickness it was assumed as a negative answer.

\section{RESULTS}

Data collection took place from March to June 2012. Twenty-three rowers including one female took part in the race. Data were collected for 12 rowers, giving roughly $52 \%$ participation rate, including the woman's data. She was the first contestant who dropped out after 8 days at sea. Average age was 46.6 years and median age was 48 years. The age range was 27 and 61 years. The average time spent at sea was 38 days. The average daily rowing time was $10.3 \mathrm{~h}$ per $24 \mathrm{~h}$. Most of their physical activity took place during daytime (Table 1).

The average number of daily meals was between 3 and 5 in $24 \mathrm{~h}$, each rower supplemented their food intake by snacking throughout the day. The daily energy intake was at about $5400 \mathrm{kcal}$. Weight loss ranged from $5.5 \%$ to $18.8 \%$ of initial bodyweight (Table 2). Only a third of participants resorted to vitamin supplements. $83 \%$ of them used dry food together or instead of regular food. Average daily water intake was $3.8 \mathrm{~L}$. Three rowers had to limit themselves to $2 \mathrm{~L}$ or less because of a water supply failure. Each rower managed their sleep cycle differently (Table 3). The amount of sleep over $24 \mathrm{~h}$ was limited. It was split in 3.8 episodes for a total time of $6 \mathrm{~h}$ and $12 \mathrm{~min}$. Almost $92 \%$ of the rowers slept during night-time. Among our study group of 12 contestants, nine had restorative sleep while the other 3 managed lighter sleep. None of them used psychostimulating drugs. Three people trained for sleep on land. Their programme included a specialist study of sleep patterns, giving up caffeine and sleeping on board before departure. The main medical problems encountered are summarised in Table 4. Most of the medical problems were skin problems, particularly infected abrasions. Lesions were mostly observed on the area of skin continuously in contact with water, friction zones (feet, hands, buttocks, groin, and inguinal folds) and the hypogastric and peri-umbilical regions. Stage 1 sun burns were described. The second most frequent complaint was trauma, joint problems and accidents. Several thermal skin burns without mention of the stage were described on hands and feet due to a gas stove or hot water. One of the rowers suffered a jellyfish sting which caused a skin burn. Digestive troubles affected close to $17 \%$ of rowers. Dysgeusia, diarrhoea and constipation were mainly linked to eating dry food. Four rowers described seasickness for 2 to 5 days without vomiting. Seven of them complained of a sense of unbalance ranging from $45 \mathrm{~min}$ to over 6 days upon returning to land. Approximately $46.2 \%$ used some kind of preventive or curative therapy against seasickness. Two people benefited from optikinetic rehabilitation on 
Table 2. Food and water intake features, weight features

\begin{tabular}{|c|c|c|c|c|c|c|c|}
\hline \multirow[t]{2}{*}{ Rower/Sex } & \multirow{2}{*}{$\begin{array}{l}\text { Daily meals } \\
\text { number }\end{array}$} & \multirow{2}{*}{$\begin{array}{l}\text { Eating time } \\
\text { [min] }\end{array}$} & \multirow{2}{*}{$\begin{array}{l}\text { Daily energy } \\
\text { intake [kcal] }\end{array}$} & \multirow{2}{*}{$\begin{array}{l}\text { Daily water } \\
\text { intake [L] }\end{array}$} & \multicolumn{2}{|l|}{ Weight [kg] } & \multirow{2}{*}{$\begin{array}{l}\text { Variation in } \\
\text { weight [\%] }\end{array}$} \\
\hline & & & & & Departure & Arrival & \\
\hline A/Male & 3 & 30 & 5000 & 4 & 88 & 79 & -10.3 \\
\hline B/Male & 5 & 10 & 6000 & 1,75 & 85 & 76 & -10.6 \\
\hline C/Male & 3 & 20 & 4500 & 1 & 86 & 76 & -11.6 \\
\hline D/Male & 5 & 10 & 5000 & 4 & 97 & 83 & $-14, .5$ \\
\hline E/Female & 3 & 30 & NR & 2 & NR & NR & NR \\
\hline F/Male & 3 & 30 & 6000 & 5.5 & 76 & 70 & -7.9 \\
\hline G/Male & 2 & 20 & NR & 5.5 & 104 & 84.5 & -18.8 \\
\hline H/Male & 5 & 10 & 5000 & 4 & 86 & 73 & -15.1 \\
\hline I/Male & 3 & 30 & 4000 & 4 & 72 & 68 & -5.5 \\
\hline $\mathrm{J} /$ Male & 3 & 30 & 6000 & 4 & 92 & 75 & -18.5 \\
\hline K/Male & 3 & 30 & 7000 & 5 & 82 & 75 & -8.5 \\
\hline L/Male & 3 & 60 & 5500 & 5 & 75 & 66 & -12 \\
\hline Average & 3.4 & 25.8 & 5400 & 3.8 & 94.3 & 82.55 & -13.3 \\
\hline
\end{tabular}

NR - not recorded

Table 3. Daily sleep

\begin{tabular}{llll}
\hline $\begin{array}{l}\text { Rower/ } \\
\text { /Sex }\end{array}$ & $\begin{array}{l}\text { Daily } \\
\text { sleeping } \\
\text { time* }\end{array}$ & $\begin{array}{l}\text { Sleeping } \\
\text { time* } \\
\text { /episode }\end{array}$ & $\begin{array}{l}\text { Number of } \\
\text { sleeping } \\
\text { episodes } \\
\text { per day }\end{array}$ \\
\hline A/Male & 4 & $\mathrm{NC}$ & $\mathrm{NC}$ \\
B/Male & 5 & 5 & 1 \\
C/Male & 9 & 0.5 & 18 \\
D/Male & 6 & 2 & 3 \\
E/Female & 6.5 & 6.5 & 1 \\
F/Male & 5 & $\mathrm{NI}$ & $\mathrm{NI}$ \\
G/Male & 8 & 8 & 1 \\
H/Male & 6 & 1 & 6 \\
I/Male & 6.5 & $\mathrm{NI}$ & $\mathrm{NI}$ \\
J/Male & 6 & 3 & 2 \\
K/Male & 6 & 6 & 1 \\
L/Male & 6.5 & 6.5 & 1 \\
Average & 6.2 & 4.2 & 3.8 \\
time & & & \\
*Times are displayed in hours; $\mathrm{NC}-$ not recorded; NI - not interpretable & &
\end{tabular}

land beforehand. Reported stress and anxiety have been attributed to a critical situation for two rowers. A pre-existing anxiety before the departure was reported for a contestant but not included in the data because this symptom completely disappeared during the race. Three rowers reported having hallucinations. They were auditory (human voices) and visual (seeing sails at sea). Only one rower mentioned psychological preparation before the race (without specifica-
Table 4. Main medical symptoms experienced during the race

\begin{tabular}{|c|c|c|}
\hline Specialty & $\begin{array}{l}\text { Cumulative } \\
\text { incidence [\%] }\end{array}$ & Symptoms \\
\hline Dermatology & 92 & $\begin{array}{l}\text { Blister } \\
\text { Boil } \\
\text { Cutaneous abscess } \\
\text { Vesicles } \\
\text { Pustules } \\
\text { Redness }\end{array}$ \\
\hline Trauma & 83 & $\begin{array}{l}\text { Tendinitis } \\
\text { Knee pain } \\
\text { Neck pain } \\
\text { Mild head trauma } \\
\text { Thermal burn } \\
\text { Sting }\end{array}$ \\
\hline $\begin{array}{l}\text { Disembarkation } \\
\text { syndrome }\end{array}$ & 58 & Unbalance \\
\hline \multirow{2}{*}{$\begin{array}{l}\text { Psychiatric } \\
\text { symptoms }\end{array}$} & 17 & Acute panic attack/anxiety \\
\hline & 25 & $\begin{array}{l}\text { Auditory (human voices)/ } \\
\text { /visual (seeing sails at } \\
\text { sea) hallucinations }\end{array}$ \\
\hline Sea-sickness & 33 & $\begin{array}{l}\text { Fatigue } \\
\text { Anorexia } \\
\text { Nausea }\end{array}$ \\
\hline Digestive system & 17 & $\begin{array}{l}\text { Dysgeusia } \\
\text { Diarrhoea } \\
\text { Constipation }\end{array}$ \\
\hline Neurology & 8 & Chronic headache \\
\hline
\end{tabular}

tion on the programme). One case of chronic headaches was described. There wasn't any mention of ophthalmological problems during this trip. 
Each rower had a first aid kit on board, $83 \%$ of them used it and found it well suited to their needs. Four rowers called for a remote medical consultation through the race organisation. One of them contacted the Telemedical Maritime Assistance Service (TMAS) based in Toulouse, south east of France, after suffering from a jellyfish sting. A first aid training session was attended before departure by $58 \%$ of participants.

\section{DISCUSSION}

This study aims to describe physiological and medical problems reported by single-handed rowers during a transoceanic race. Just over half of the rowers returned our questionnaire providing this work with a satisfactory sample. There are only few studies on this specific subject, while those on nautical sports, whether rowing, sailing, in competition or for leisure, are widespread.

Skin problems, because of the constant seawater contact and the rubbing of boat or clothes were the main problem. These symptoms had already been described in a study on two transoceanic rowers [3] and on athletic rowers performing short races. They suffered from blisters and skin irritation complicated by itching and lichenification [2]. These symptoms are more prominent in a transatlantic race because of the exaggerated length of the race.

Trauma has often been observed in intensive rowers. Back and knee pain are most frequent [1, 2]. Back problems were not reported in this study, which does not exclude their presence. Rowers mainly complained of neck pain and tendinitis, especially in knees. Boat configuration prevented standing and added to the day's trauma by preventing muscle recovery, which was deemed responsible for the neck pain. Although previously described in scientific literature, rowers did not mention costal thoracic pain seen in costal stress fractures. These however were often observed during intensive training.

The race took place in hot and humid conditions because of the race latitude. These conditions are taxing on the human body leading to dehydration and hyperthermia. Food and hydration have to be adjusted to maintain a stable weight in order to sustain the best physical performances. Protein, lipid, vitamin and nutrient intake have to be modified to meet needs [6]. A good homeostasis helps to maintain a healthy cardio-pulmonary function to maintain and, as a consequence, adequate physical performance. Dehydration has to be prevented since it would impair sporting performance by decreasing blood volume, therefore impairing cardio-respiratory function [7]. Slater et al. [8] studied rowers' performance in different conditions. Physical performance decreased in hot and humid conditions. This decrease intensified in case of weight loss and dehydration. Weight loss affected all our rowers, ranging from $5.5 \%$ to $18.8 \%$ of their initial weight. This happened despite an average daily food intake of $5400 \mathrm{kcal}$. The physical work required for this race was intense and energy loss was superior to intake. A $9 \mathrm{~kg}$ and $11 \mathrm{~kg}$ weight loss had already been witnessed in transoceanic rowers despite an energy intake of $8000 \mathrm{kcal}$ [3]. A first aid kit was on board. The preparation of this kit was considered satisfactory since the users found it well adapted to the medical problems they encountered. Means of communication with land (essentially the telemedical maritime assistance service) were only used once, as the first aid kit was large enough for on board medical problems.

Only four cases of seasickness were reported during this race. They reached stage 2 at the most, according to the Graybiel and Miller classification [9]. Around half of the rowers used a treatment against seasickness. The two rowers who took part in preventive optokinetic rehabilitation did not feel any seasickness. Medical treatments such as antihistamines (dimenhydrinate, diphenyldramine) or anticholinergics (scopolamine), all presented side effects. In addition, they may not work in some people. Optokinetic rehabilitation - whether to prevent or cure seasickness reproduces a sensory conflict by providing patients with proprioceptive, visual and vestibular information. Several studies have showed the efficiency of this technique in preventing or treating seasickness without side effects $[10,11]$. This therapy may be of interest to the developing sailing population and may be worth further research.

Sleep management remains a major problem during long-term nautical activities, especially during single handed or small crew sailing competitions [12]. Single-handed rowing permits longer sleeping time than solo sailing and allows some rowers to have a relatively long single night-time episode of sleep. $75 \%$ of the rowers reported restorative sleep. Knowledge of their sleep rhythm is very important to maintain optimal physical performances and adequate psychomotor awareness. Sleep impacts on sporting performance and results. When adequate, it helps to limit physical accidents by maintaining adequate psychomotor awareness. It was shown that attention decreases a lot during sleep deprivation of less than $7 \mathrm{~h}$ daily. An essential minimum threshold would be less than $4 \mathrm{~h}$ of sleep per day [13].

This race has isolated rowers for an average of 38 days. Work performed in isolated conditions, among polar expedition scientists showed the emergence of psychological troubles. They mainly consisted of fatigue, weight gain, sleep problems, depressed mood, anxiety, irritability and social conflicts due to living in close proximity [14]. Our rowers did not describe serious problems apart from anxiety and hallucinations. The race was much shorter than the polar expedition and communication was possible with land or other 
contestants. That allowed them to fare better in terms of solitude and anxiety generated by the race. It is necessary to continue studying mental state in isolated contexts whether in polar expeditions or long offshore navigation in order to better prepare individuals for, among other things, maritime isolation. Results of these studies could also benefit other fields, including aeronautical, for instance. With the aim of reaching distant planets, it is necessary to gather data on human feelings and mental state in isolated situations. Studies have looked at situations of isolation lasting over a year [15]. Data on mental states in isolation have led to improvement in preparative procedures for scientists, whether sailors or other, before long term isolation on expeditions, boat races or other missions.

\section{LIMITATIONS OF THE STUDY}

This is a retrospective study and could not be exhaustive, but more than half of the participants were being studied, making it the largest current series in this type of activity. Unfortunately, it represents only trained people and even if our sample is not representative of the general population, our results are useful for others sportive contestants as rowers and sailors. In nowadays, sailing races are getting more popular and this study provides data on general health for sportive humans at sea. Data obtained about one female are not very informative because she dropped out after 8 days due to technical matters but at sea, racers are in the large majority males. The methodology was poorly adapted to the study of psychological problems which probably led to an underestimation of them.

\section{CONCLUSIONS}

The physiological and psychological impact of this type of event is still unclear. The psychological state and quality of preparation are important factors for success. They were undervalued but contributed to the failures and dropouts. Nautical sports are widespread in mankind. Races at sea, especially transoceanic ones, use different types of boats and are starting to open to the general, less experienced public who are certainly going to need more preparation and training beforehand. The medical information collected in this study will help to improve those training programmes, meaning contestants can start races in better conditions. This work will need to be pursued and to include other types of races such as long-haul sailing, whether single handed or in a team. Sailors are subject to different stress conditions depending on the type of race. A better sensitisation of the contestants to studies will improve the quality of the data gathered. This data on mental state over isolated periods could also interest the scientific community looking into longer expeditions in complete isolation.

\section{REFERENCES}

1. Hosea TM, Hannafin JoA. Rowing injuries. Sports Health. 2012; 4(3): 236-245, doi: 10.1177/1941738112442484, indexed in Pubmed: 23016093.

2. Rumball JS, Lebrun CM, Di Ciacca SR, et al. Rowing injuries. Sports Med. 2005; 35(6): 537-555, indexed in Pubmed: 15974636.

3. Clark N, Coleman C, Figure K, et al. Food for trans-Atlantic rowers: a menu planning model and case study. Int J Sport Nutr Exerc Metab. 2003; 13(2): 227-243, indexed in Pubmed: 12945831.

4. Weiss E. Effects of rowing on humeral strength. Am J Phys Anthropol. 2003; 121(4): 293-302, doi: 10.1002/ajpa.10240, indexed in Pubmed: 12884311.

5. Rames Guyane 2012. Available at http://www.ramesguyane. com/ (Accessed April 15, 2012).

6. American Dietetic Association, Dieticians of Canada, American College of Sport Medicine, Rodriguez NR, Di Marco NM, Langley S. American College of sports medicine position stand. Nutrition and athletic performance. Med Sci Sports Exerc. 2009; 41(3): 709-731.

7. Burge $\mathrm{CM}$, Carey MF, Payne WR. Rowing performance, fluid balan$\mathrm{ce}$, and metabolic function following dehydration and rehydration. Med Sci Sports Exerc. 1993; 25(12): 1358-1364, indexed in Pubmed: 8107542.

8. Slater GJ, Rice AJ, Tanner R, et al. Impact of acute weight loss and/ or thermal stress on rowing ergometer performance. Med Sci Sports Exerc. 2005; 37(8): 1387-1394, indexed in Pubmed: 16118587.

9. Graybiel A, Wood CD, Miller EF, et al. Diagnostic criteria for grading the severity of acute motion sickness. Aerosp Med. 1968; 39(5): 453-455, indexed in Pubmed: 5648730.

10. Trendel D, Haus-Cheymol R, Erauso T, et al. Rééducation optocinétique dans la prévention du mal de mer. Annales françaises d'Oto-rhino-laryngologie et de Pathologie Cervico-faciale. 2010; 127(4): 162-167, doi: 10.1016/j.aforl.2010.07.014.

11. Ressiot E, Dolz M, Bonne L, et al. Étude prospective sur l'efficacité de la rééducation optocinétique dans le traitement des naupathies. Annales françaises d'Oto-rhino-laryngologie et de Pathologie Cervico-faciale. 2013; 130(5): 268-273, doi: 10.1016/j. aforl.2013.02.010.

12. Léger D, Elbaz M, Raffray T, et al. Sleep management and the performance of eight sailors in the Tour de France la voileyacht race. J Sports Sci. 2008; 26(1): 21-28, doi: 10.1080/02640410701348636, indexed in Pubmed: 17896286.

13. Belenky G, Wesensten NJ, Thorne DR, et al. Patterns of performance degradation and restoration during sleep restriction and subsequent recovery: a sleep dose-response study. J Sleep Res. 2003; 12(1): 1-12, indexed in Pubmed: 12603781.

14. Palinkas LA, Suedfeld P. Psychological effects of polar expeditions. Lancet. 2008; 371(9607): 153-163, doi: 10.1016/S01406736(07)61056-3, indexed in Pubmed: 17655924.

15. Basner M, Dinges DF, Mollicone DJ, et al. Psychological and behavioral changes during confinement in a 520-day simulated interplanetary mission to mars. PLoS One. 2014; 9(3): e93298, doi: 10.1371/ journal.pone.0093298, indexed in Pubmed: 24675720. 